\title{
What Do Byssus and Crimson Imply about the Hebrew Bible and the Septuagint?
}

\author{
ANNA RAMBIERT-KWAŚNIEWSKA \\ Instytut Nauk Biblijnych, Papieski Wydział Teologiczny we Wrocławiu \\ e-mail: anna.rambiert@gmail.com \\ ORCID: 0000-0002-9491-6786
}

\begin{abstract}
Summary: Fabrics such as byssus and crimson wool can provide us with a surprisingly large amount of information about the circumstances of Biblical books origin. Analysis of lexis related to mentioned textiles, present in Exodus and in Chronicles, allows to notice a meaningful change, occurring in technical biblical terminology. In Exodus,

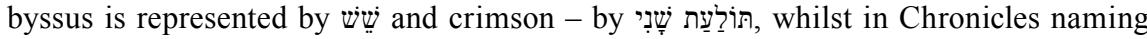

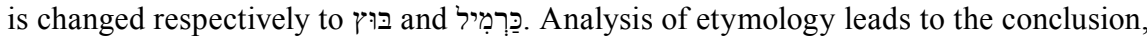
that textiles mentioned in Torah belong to an early vocabulary, created in the times before the exile, in Chronicles, on the other hand, encountered terms belong to period of Babylonian captivity or after the exile. Confrontation of these textiles with the other, non-biblical sources, provides a confirmation of proposed dating and facilitates identification of mysterious biblical byssus, which turns out to be a very thin linen and not - as sometimes confused - sea silk. Juxtaposition of the Greek equivalents allows to draw a conclusion, that terminology of both Torah and Chronicles was known to the LXX translators, who - despite a clear caesura - translate terms consequently: שש and

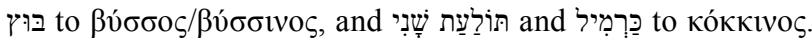

Keywords: byssus, crimson, textiles, colors, fabric, Exodus, Chronicles, Septuagint, Hebrew Bible

The he research on the Biblical material culture constitutes mainly the archeological domain. The Biblicists reach for it readily in order to come to conclusions as regards the text. What is of a popular interest here is mainly sculpture, glyptic, writing culture and architecture. It is rare for the research to focus on the more prosaic elements of everyday life, such as wine, food or textile production. As far as the last case goes, the most numerous are the studies regarding purple. It is one of many fabrics (we are considering here not the color but the wool dyed

1 The article contains the unpublished elements of the doctoral dissertation „The Textiles in the Hebrew and the Old Testament", defended by the author in the Institute of the Classical, Mediterranean and Oriental Studies on 31 January, 2017. Thesis described in this article have been presented during International Conference SBL in Berlin 2017, and then shared on: https:// pwt-wroc.academia.edu/AnnaRambiertKwasniewska. 
with the secretion produced by snails of Muricidae family) named in the Bible that can bring some knowledge about not only the everyday life, but also about the text itself. There are two biblical fabrics that are worth special mentioning i.e. byssus (snow-white, delicate fabric) and crimson (deep red, produced from insects called Coccus). Their uniqueness comes from the terminology, which reveals how the language of the Bible changed over the centuries, how it was influenced by different factors, including the changing of the trade routes, wars, culture, relations with neighbors etc.

Producing the reliable results requires a multi-layer research. Firstly, I am going to discuss shortly the history of byssus and crimson in the Ancient Middle East and Egypt. Subsequently, I am going to present and interpret the list of textile terms in Hebrew and Greek for the Book of Exodus and the Book of Chronicles since those are in this respect the most reliable. Next, I am going to present the Hebrew terminology that is connected with byssus and crimson - putting a special emphasis on the etymology of the terms themselves - and their Greek equivalents. The aim of the research is going to be the answer to the question what kind of information can be delivered through textiles with - their history and terminology - and about the text of the Bible.

\section{Byssus and Crimson - origins}

At first glance the term "byssus" can quite easily guide towards the mistake of anachronism - this is thanks to a common - and incorrect - practice of identifying it with a so called "sea silk", produced from mucus of sea mussels, for example Pinna nobilis L. The correct meaning, however, of the original Semitic

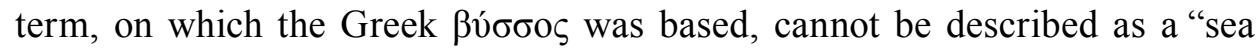
silk" - it most of all meant a high-quality linen, and - later on - a high-quality silk and even cotton. ${ }^{2}$ We should agree with Harlow, Noch and Maeder, that using a term "byssus" in a biblical context is a result of misunderstanding, ${ }^{3}$ as

2 R. Beekes - L. van Beck, Etymological Dictionary of Greek (LIEEDS 10; Leiden -Boston: Brill 2009) I, 249; It is particularly strange that Szczepanowicz in his book that aspires to be a popular science one does not mention identifying byssus and crimson which constitutes in this case an absolute keystone, but states only that "The Bible also names the byssus the most delicate, the thinnest and the linen of the highest quality". B. Szczepanowicz, Moda w Biblii (Kraków: Wydawnictwo Księży Sercanów DEHON 2011) 113.

3 Flicitas Maeder believes that the source of confusion regarding byssus comes probably from an incorrect interpretation of the Aristotle's fragment (HA 547b15-16), in which the Greek ó $\beta v \sigma \sigma o ́ \varsigma$ ("sea deapth") was mistakenly taken for $\dot{\eta} \beta v ́ \sigma \sigma o \varsigma$ ("a perfect thin fabric"). As a result of a semantic misunderstanding, dated for approx. $15^{\text {th }}$ century AD, there appeared a fabric that came from the sea depth so "a sea silk". F. Maeder, "Irritating Byssus - Etymological Problems, Material Facts, and the Impact of Mass Media", Textile Terminologies from the Orient to the 
the original name of a "sea silk" was at that time de facto unknown. The oldest findings of byssus are dated from $4^{\text {th }}$ century $\mathrm{AD},{ }^{4}$ and written from $2^{\text {nd }} \mathrm{AD}-$

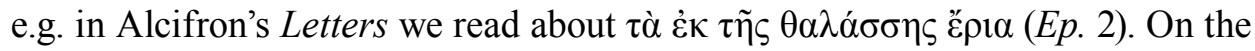
other hand, fabrics made of a thin high-quality linen appear in the handwritten testimonies as old as $9^{\text {th }}$ century $\mathrm{BC}$ and have numerous representations within the texts from Nineveh library. ${ }^{5}$

We can reach the conclusion that a so called byssus from the 1st century BC came from Egypt. The textiles made of linen fibers were already produced in the neolith and its long history resulted in a unique specialization since the Egyptians were able to weave the threads thinner than $50 \mu \mathrm{m} .{ }^{6}$ Egyptian origin of a fine linen is mentioned at least by the Neo-Babylonian texts (CT 2 2). "Byssus" was also found in the Book of Ezekiel - "Embroidered linen from Egypt was used for your sail and for your flag" $(27,7$; NJB) as well as in cuneiform letter by king of Cyprus found in Amarna (EA 34). ${ }^{7}$ It appears also on Rosetta Stone, where it is described as "royal linen". ${ }^{8}$ And speaking of linen, it is worth mentioning that the linen textiles belong to the oldest ones authenticated by archaeology. It is also worth mentioning that since we are talking about the Bible that on the Judean Desert there has been found the evidence for the presence of linen in about year 6500 BC. ${ }^{9}$

Another set of terms that is particularly interesting is the one referring to crimson (to be more precise: to wool dyed in a crimson colour). It was brought to Israel during its biblical period most probably by Assyrians. It is believed that ability to dye fabric using insects, so called Armenian cochineal, was brought by Sargon II, coming back from his invasion on Urartu in $714 \mathrm{BC}$ - if we agree to understand "red things from Ararat and Khurkhni" as description of crimson. Another important information regarding the origin of crimson is a fact that around 1100 years BC Tiglat-Pileser brought to Assyria a kind of oaks, called

Mediterranean and Europe, 1000 BC to 1000 AD (ed. S. Gaspa - C. Michel - M.-L. Nosch) (Lincoln: Zea Books 2017) 505-506.

4 M. Harlow - M.-L. Nosch, "Weaving the Threads: Methodologies in Textile and Dress Research for the Greek and Roman World - the State of the Art and the Case for Cross-Disciplinary", Greek and Romans Textiles and Dress: An Interdisciplinary Anthology (ed. M. Harlow M.L. Nosch) (ATS 19; Oxford: Oxbow Books 2014) 16.

5 A.L. Oppenheim, "Essay on Overland Trade in the First Millennium B.C.", Journal of Cuneiform Studies 21 (1967) 249-250.

6 Maeder, Irritating Byssus, 502.

7 Oppenheim, „Essay on Overland Trade”, 249-250.

8 Maeder, Irritating Byssus, 501; see Oppenheim, „Essay on Overland Trade”, 249; A.H. Gardiner, "Two hieroglyphic signs and the Egyptian words for «Alabaster» and «Linen»", Bulletin de l'institut francais d'archeologie orientale 30 (1930) 171-176.

9 O. Shamir, "Textile Production in Eretz-Israel", Michmanim 16 (2002) 19; Z.C. Koren, "The Colors and Dyes on Ancient Textiles in Israel", Colors from Nature: Natural Colors in Ancient Times (Tel Aviv: Eretz Israel Museum 1993) 15. 
Kermes Oaks, which are natural habitat for insects called Kermes scales. ${ }^{10}$ That leads Koren to conclusion that the insect used as a source of biblical crimson was - mentioned previously - Armenian cochineal. ${ }^{11}$ Other scientists, however, disagree by pointing out, that evidence for the presence of another species Kermes echinatus - living on Kermes Oaks (Quercus calliprinos) can be found at around $70 \mathrm{AD} .^{12}$

After this short introduction one can agree that both the white byssus fabrics and the wool dyed in crimson were most probably often present on the Israel markets in the biblical times. How can this knowledge relate to the biblical terminology? Giving a satisfactory response to this question requires analysing the textile terminology from the Book of Exodus and the Books of Chronicles.

\section{Byssus in Exodus and Chronicles}

Throughout the Torah, "byssus" - שׁ is most commonly mentioned in conjunction with blue purple, purple from Tyr and with crimson. It is listed among the materials used to build Tabernacle $(25,4)$ and it is consequently translated as

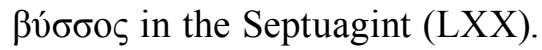

\begin{tabular}{|c|c|c|}
\hline \multicolumn{3}{|c|}{ Fine linen (byssus) } \\
\hline Hebrew term & GREEK TERM & Siglum \\
\hline שֶׁשׁ & 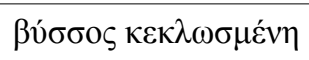 & Exod 25,4 \\
\hline שׁשׁש מָשְׁזָר & 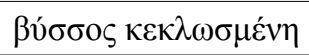 & Exod 26,1 \\
\hline שֶׁשׁ מָשֶׁזָר & 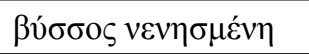 & Exod 26,31 \\
\hline שׁׁשׁ מָשָׁזָר & 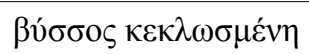 & Exod 26,36 \\
\hline
\end{tabular}

10 Koren, "The Colors and Dyes", 26; Akkad. allankaniš, where kanaš, coming probably from Hittite, means a dye, and akkad. allanu - an oak. R.J. Forbes, Studies in Ancient Technology (Leiden: Brill 1956) IV, 103, 142.

11 The crimson dye obtained from an insect living in the mountain was believed in the times of Talmud Bavli (Menahot IX,6) to be the only acceptable source of crimson fabrics used in the sacred garments. Although both, Koremes vermillo and the Armenian cochineal (Porphyrophora hamelii) live in the mountains, it is more probable that „sacred" dye was obtained exclusively from the latter. Koren, "The Colors and Dyes", 24-26; Sukenik menions also Laccifer lacca from the kerriidae family. N. Sukenik, „Dyes in Eretz Israel in the Roman Period, in Light of the Textile Findings from the Judean Desert Caves", Cathedra 154 (2014) 24-25.

12 The last references about the use of שָׁ who mentiones the symbolism of crimson connected with fire and the regulations introduced by Jewish elders, who announcing the time of the national mourning prohibited the wedding guests to wear crimson clothing and gold. Z. Amar-H. Gottlieb - L. Varshavsky, "The Scarlet Dye of the Holy Land", Bioscience 12/55 (2005) 1080-1081. 


\begin{tabular}{|c|c|c|}
\hline \multicolumn{3}{|c|}{ Fine linen (byssus) } \\
\hline Hebrew term & GREEK TERM & Siglum \\
\hline 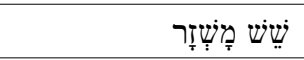 & $\beta v ́ \sigma \sigma o \zeta ~ \kappa \varepsilon \kappa \lambda \omega \sigma \mu \varepsilon ́ v \eta$ & Exod 27,9 \\
\hline שֶׁשׁ מָשְָָׁר & $\beta v ́ \sigma \sigma o \zeta ~ \kappa \varepsilon \kappa \lambda \omega \sigma \mu \varepsilon ́ v \eta$ & Exod 27,16 \\
\hline שֶׁש מָשֶׁזָר & $\beta v ́ \sigma \sigma o \zeta ~ \kappa \varepsilon \kappa \lambda \omega \sigma \mu \varepsilon ́ v \eta$ & Exod 27,18 \\
\hline שֶׁשׁ & $\beta \tilde{\sigma \sigma \sigma o s}$ & Exod 28,5 \\
\hline 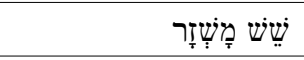 & $\beta ט ́ \sigma \sigma o \zeta ~ \kappa \varepsilon \kappa \lambda \omega \sigma \mu \varepsilon ́ v \eta$ & Exod 28,6 \\
\hline 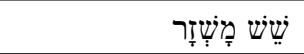 & 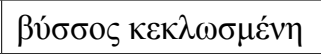 & Exod 28,8 \\
\hline שׁשׁש מָשְׁזָר & 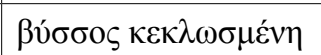 & Exod 28,15 \\
\hline 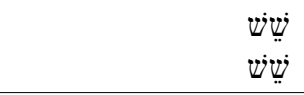 & 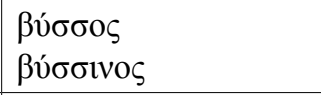 & Exod 28,39 \\
\hline שֶׁש & 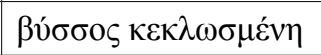 & Exod 35,6 \\
\hline שֶׁשׁ & $\beta v ́ \sigma \sigma o \varsigma$ & Exod 35,23 \\
\hline שֶׁשׁ & $\beta \tilde{\sigma \sigma \sigma o \zeta}$ & Exod 35,25 \\
\hline שֶׁשׁ & $\beta v ́ \sigma \sigma o \varsigma$ & Exod 35,35 \\
\hline שֶׁשׁ מָשְׁזָר & - & $\begin{array}{l}\text { Exod 36,8 (HB)/ Exod } \\
36,8 ; 37,1(\mathrm{LXX})\end{array}$ \\
\hline 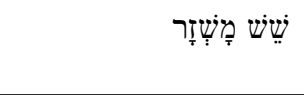 & 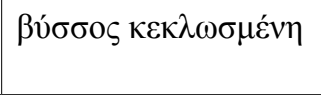 & $\begin{array}{l}\text { Exod 36,35 (HB)/ Exod } \\
37,3(\mathrm{LXX})\end{array}$ \\
\hline שֶׁש מָשְׁזָר & $\beta v ́ \sigma \sigma o \zeta ~ \kappa \varepsilon \kappa \lambda \omega \sigma \mu \varepsilon ́ v \eta$ & $\begin{array}{l}\text { Exod 36,37 (HB)/ Exod } \\
37,5(\mathrm{LXX})\end{array}$ \\
\hline שֶׁשׁ מָשְׁזָר & 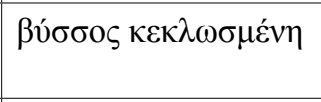 & $\begin{array}{l}\text { Exod 38,9 (HB)/ Exod 37,7 } \\
(\text { LXX) }\end{array}$ \\
\hline שֶׁשׁ מָשֶׁזָר & 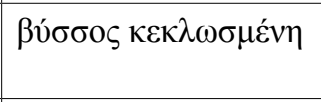 & $\begin{array}{l}\text { Exod 38,16(HB)/ Exod } \\
37,14(\mathrm{LXX})\end{array}$ \\
\hline שֶׁשׁ מָשְׁזָר & $\beta v ́ \sigma \sigma o \zeta ~ \kappa \varepsilon \kappa \lambda \omega \sigma \mu \varepsilon ́ v \eta$ & $\begin{array}{l}\text { Exod 38,18 (HB)/ Exod } \\
37,16(\mathrm{LXX})\end{array}$ \\
\hline שֶׁשׁ & $\beta \tilde{\sigma \sigma \sigma o \varsigma}$ & $\begin{array}{l}\text { Exod 38,23 (HB)/ Exod } \\
37,21(\mathrm{LXX})\end{array}$ \\
\hline שֶׁש מָשֶׁזָר & 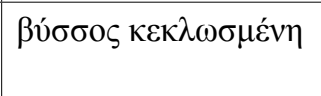 & $\begin{array}{l}\text { Exod 39,2 (HB)/ Exod 36,9 } \\
(\text { LXX) }\end{array}$ \\
\hline שֶׁשׁ & $\beta v ́ \sigma \sigma o \zeta ~ \kappa \varepsilon \kappa \lambda \omega \sigma \mu \varepsilon ́ v \eta$ & $\begin{array}{l}\text { Exod 39,3 (HB)/ Exod } \\
36,10(\mathrm{LXX})\end{array}$ \\
\hline 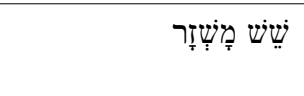 & 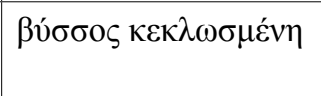 & $\begin{array}{l}\text { Exod 39,5 (HB)/ Exod } \\
36,12(\mathrm{LXX})\end{array}$ \\
\hline 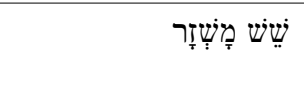 & 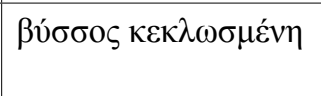 & $\begin{array}{l}\text { Exod 39,8 (HB)/ Exod } \\
36,16(\mathrm{LXX})\end{array}$ \\
\hline
\end{tabular}




\begin{tabular}{|c|c|c|}
\hline \multicolumn{3}{|c|}{ Fine linen (byssus) } \\
\hline Hebrew term & GREEK TERM & Siglum \\
\hline שׁِשׁ & $\beta$ & $\begin{array}{l}\text { Exod 39,27 (HB)/ Exod } \\
36,34(\mathrm{LXX})\end{array}$ \\
\hline 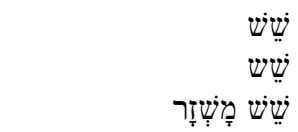 & 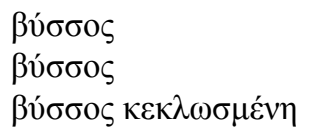 & $\begin{array}{l}\text { Exod 39,28 (HB)/ Exod } \\
36,35(\mathrm{LXX})\end{array}$ \\
\hline שֶׁשׁ מָשֶָָׁר & $\beta v ́ \sigma \sigma o \varsigma$ & $\begin{array}{l}\text { Exod 39,29 (HB)/ Exod } \\
\text { 36,36 (LXX) }\end{array}$ \\
\hline
\end{tabular}

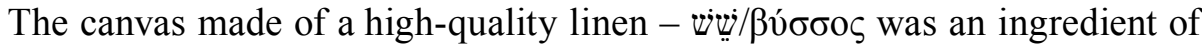
the curtain in front of the Holy of Holies (26,31; variant ששיש מש ש is confirmed here also by 4QpaleoGenExod, fr. 30 II, 31), in 4QpaleoGenExod', fr. 30 II, 34). It was also a base for the curtain on the courtyard of Tabernacle, on the south side (27,9.18; see ששושז in. 2QExod, fr. 6). The same kind of linen, among other yarns, was used in creation of the curtain covering the main entrance to the courtyard $(27,16)$. Even the robes of the priests were all woven using "byssus" $(28,5)$ - not only was it an ingredient of ephod's waistband (28,8; see שש מש in 4QpaleoExod" ${ }^{\mathrm{m}}$, col. XXXI, 8) and pectoral $(28,15$; both created from mixed threads), but it was also a sole ingredient of the ephod ${ }^{14}$ itself: however, only in LXX, which at this point departs from the Hebrew text, wherein both purple, crimson and other fabrics are mentioned next to "byssus". According to TH the robe that Aaron would put on directly on his body was supposed to be made entirely out of byssus, so was to be the tiara $(28,39)$. TG gives, however, a different account. In his opinion, it was the chiton tassels that were supposed to be made of linen ( $\beta v ́ \sigma \sigma o \varsigma)$, but when it comes to the tiara he agrees with the Hebrew account and he uses the adverb "linen"-

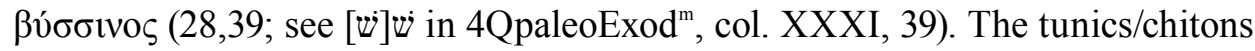
of Aaron and his sons $(39,27 / 36,34)$ as well as the tiara, mitra and trousers

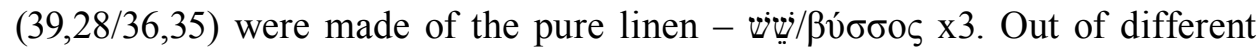

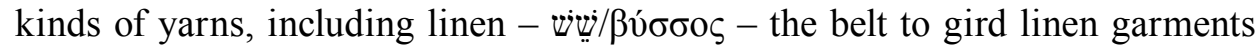
was spun. $(39,29 / 36,36)$. The above analysis clearly pictures consequence of the Hebrew writer, persistently using שׁ as well as of the author, who used $\beta v ́ \sigma \sigma o \varsigma$

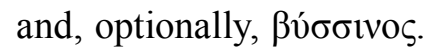

13 Cf. L.H. Schiffman, The Courtyards of the House of the Lord. Studies on the Temple Scroll (STDJ 75; Leiden -Boston: Brill 2008) 258nn.

14 More information on ephod and its three types - a kind of cult garments, ,a permanent ephod" and the element of the archpriest garment can be found in: C. Houtman, Exodus (HCOT; Leuven: Peters 2000) III, 478nn. 
List of terms describing "byssus", this pristine white fabric, is also very interesting in Writings. Mentioned previously in Tora noun שw is here entirely

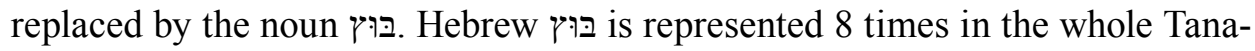
$\mathrm{kh}$, among which 7 times it appears in Writings. Most commonly - because as many times as 5 - it is used by the Chronicler. and among others on the very ground it is recognized, primarily by Avi Hurvitz, as a younger equivalent of שש, which has its proof in the form of the Hebrew Mishnah and Aramaic Targums, which use exclusively. ${ }^{15}$

\begin{tabular}{|c|c|c|}
\hline \multicolumn{3}{|c|}{ FINE LINEN (BYSSUS) } \\
\hline HEBREW TERM & Greek Term & SIGLUM \\
\hline בִֶּ & $\alpha \beta \alpha \kappa^{*}$ & $1 \mathrm{Chr} 4,21$ \\
\hline בוּוּץ & 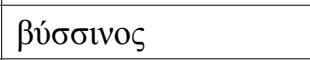 & $1 \mathrm{Chr} 15,27$ \\
\hline בּּוּץ & $\beta \tilde{\sigma \sigma o \varsigma}$ & 2 Chr 2,13 \\
\hline בוּן & $\beta v ́ \sigma \sigma o \varsigma$ & 2 Chr 3,14 \\
\hline בפוּץ & $\beta$ & 2 Chr 5,12 \\
\hline
\end{tabular}

First Book of Chronicles provides with information regarding manufacturing of $y$ ㅋ. $1 \mathrm{Chr} 4,21^{16}$ mentions about the local production, in the manufacture run by descendants of Juda in Beth-Ashbea. ${ }^{17}$ Interestingly, LXX not only wrongly translates name Beth-Ashbea, but also does not translate term r’ּ̣ a all - instead,

15 Hurvitz draws the conclusion here that the term appeared in the Hebrew language only in $6^{\text {th }}$ century BC, whereas $w$ is connected with the time from before the exile. He justifies his position additionally through his remarks towards the Book of Ezekiel, that is the product of the times of Babylonian exile ( $6^{\text {th }}$ century) and it uses both the terms interchangeably. A. Hurvitz, "The Usage of שש and the Bible and Its Implication for the Date of P", The Harvard Theological Review 1/60 (1967) 118. Frederick W. Knobloch, however, disagrees with Hurvitz. Using alternative lexical analysis of source P he notices, that presence of ש Exodus cannot be treated as a proof of its pre-exilic origin. Knobloch claims that both terms

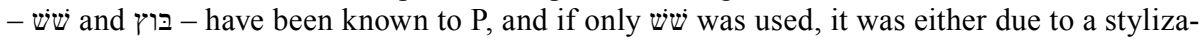
tion or to stress the Egyptian origin of priests' robes. Following this reasoning it needs to be mentioned that has indeed no reference to Egypt whatsoever. Selection of terms is therefore dependent on the context, and mentioned terms are not synonyms but names of two different fabrics. F.W. Knobloch, "Linen and the Linguistic Dating of P", Mishneh Todah. Studies in Deuteronomy and its Cultural Environment in Honor of Jeffrey H. Tigay, (ed. N.S. Fox D.A. Glatt-Gilad - M.J. Williams) (Winona Lake: Eisenbrauns 2009) 461nn.

16 In spite of the lack of mater lectionis and the doubts presented through LXX, the term did not and still does not raise doubts of the researchers and translators. See W. Gesenius, A Hebrew and English Lexicon of the Old Testament with Appendix Containing the Biblical Aramaic (trans. E. Robinson) (Boston - New York - Chicago: The Riverside Press 1906) 101; G.N. Knoppers, I Chronicles 1-9: A New Translation with Introduction and Commentary (AB 12; New York - London - Toronto: Doubleday 2004) 351.

17 The name was not identified. A. Tronina Pierwsza Księga Kronik (NKBST 10/1; Częstochowa: Edycja Świętego Pawła 2015) 151. 
author replaced translation with transcription of Hebrew term, which in result gave word $\alpha \beta \alpha \kappa .{ }^{18}$ Was it possible, that the translator had not known the noun Y크? Or maybe author by mistake associated this word with some name? This is also a plausible scenario, considering, that the same operation of using transcription instead of translation was used for much more common noun - עִבָדָה Or maybe - let us go through all possibilities - translation was based on some manuscript, which was already incorrectly copied? Whatever was the cause of mentioned mistake, we know for sure cases like $\alpha \beta \alpha \kappa$ that were not rare in Chronicles - translators were often using transcription of Hebrew terms. ${ }^{19}$ In other parts of the Book of Chronicles this error - surprisingly - disappears. is there translated to adjective $\beta v$ $\sigma \sigma \mathrm{v}$ os $(15,27)$. According to Chronicles, king David was wearing a coat made of high-quality byssus / linen during introduction of the Ark of the Covenant to Jerusalem. In the Second Book of Chronicles one can find a confirmation that ability to manufacture fabrics - and $\gamma: \exists / \beta v 0 \sigma \sigma o \zeta$ among them - was one of the king Salomon's demands on the builders of the

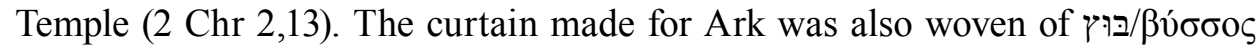
$(3,14)$ and the same white fabric was used to sew robes for Levites, when the Ark was finally brought to finished Temple $(5,12){ }^{20}$

18 An interesting language coincidence is worth mentioning here. There exists a fabric called abacá or abaka. It could not have spread, however, to Greek in the time of LXX since its name means the fibre of Manila banana leaves out of which the fabrics (which had the same name) were weaved as well as basketwork and ropes. Cf. S. Lervad - T.E. Mathiassen, "textilnet. $\mathrm{dk}$ - A Toolkit for Terminology Research and Presentation", Textile Terminologies from the Orient to the Mediterranean and Europe, 1000 BC to 1000 AD (ed. S. Gaspa - C. Michel M.-L. Nosch) (Lincoln: Zea Books 2017) 531.

19 Leslie C. Allen sees in the actions of translators a certain consequence. They are transcribing the terms that can be divided into the following groups: 1) the words that can be perceived by a translator as own names, that were associated by them with famous names or persons 2) the nouns connected with the cult that could have existed in the Diaspora not in a translation but in an original language, and in writing they started to be transcribed. In the case of $\alpha \beta \alpha \kappa$ we probably deal with the incorrect translation of the Hebrew word הבץ in which mater lectionis were missing. L.C. Allen, The Greek Chronicles. The Relation of the Septuagint of I and II Chronicles to the Masoretic Text (Leiden: Brill 1974) 62-63.

20 Knobloch's opinion, that $\gamma$ iּ is supposedly a separate type of fabric from wis strange. Of course, we can admit, that materials described by these two words could have been different in structure (different thickness of thread and warp) or in quality. Yet denying, that an equivalent of שש seems pointless in context of $2 \mathrm{Chr} 3,14$, where all the fabrics used in the process of creation of curtain of the Temple has been listed in exactly the same order as in case of curtain of the Tabernacle in Ex 36,35. Despite the fact, that both curtains have been installed on separate constructs, they are described almost identically with only one difference:

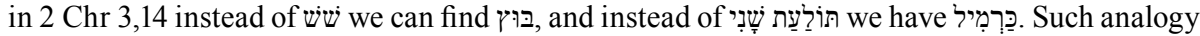
seems to also undermine Knobloch's suggestion that biblical with purple - what would be the reason for which the Chronicler, after using terms and

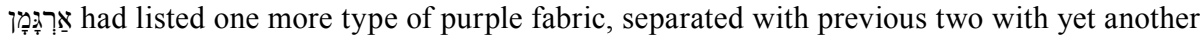
material - 
It is worth mentioning, that the Book of Esther brings even richer terminological diversity regarding expensive textiles - which shouldn't be a surprise if one consider, that action of the Book takes place in royal palace. In the text one can find two different words associated with linen textiles. First is again

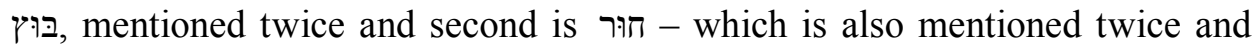
characteristic only for the Book of Esther. Both terms were used to describe palace of Ahasuerus in Est 1,6. Is there any substantial difference between these two words? Do they refer to the same kind of thread or rather to completely different textile? Or maybe unknown author decided to use two different terms motivated merely by the good writing style? Antalya Brenner votes mostly for stylistic motivation, however, she also allows to identify חith cotton. ${ }^{21}$ This issue is still unsolved, but LXX brings truly Solomonic solution: it translates

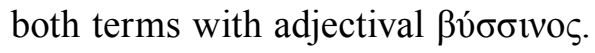

\section{Crimson in Exodus and Chronicles}

Terminology describing crimson in the Hebrew Bible (HB) also has several vari-

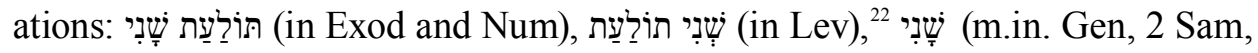

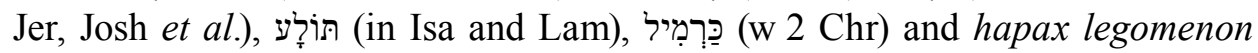
מִתִֶרֶצים (w Nah 2,4), the ones that, according to Antalya Brenner, indicate existence of a number of textual traditions. ${ }^{23}$ Most often crimson textiles in version are mentioned in the Book of Exodus.

purple it would have questioned our understanding of שש, which LXX translates using exactly these two words. See Knobloch, "Linen and the Linguistic", 463-466.

21 A. Brenner, Colour Terms in the Old Testament (JSOTSS 21; Sheffield: JSOT Press 1983) 149; Hurvitz, "The Usage of שש and 149, Unfortunately, the commentators are not willing to explore the topic since they consider the presence of cotton in the Old Testament as obvious. F.W. Bush, Ruth/Esther (WBC 9; Dallas: Word Books Publisher 1971) 347-348.

22 We do not take into account a separately standing noun (in LXX ó $\sigma \kappa \omega \dot{\lambda} \lambda \eta \xi)$ ), that may be misleading when analyzed. The notion itself means a "worm" in genere, that does not have a lot in common with an insect called kermes. In view of the above the places where the term is recorded are going to be discussed, i.e. Exod 16,20; Deut 28,39; Ps 22(21),7; Isa 41,14 (LXX

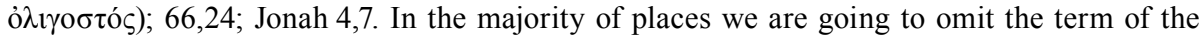

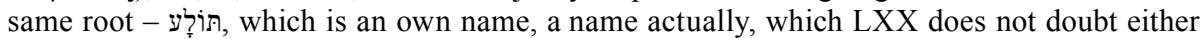
translating/transcribing it into $\Theta \omega \lambda \alpha$ (Gen 46,13; Num 26,23; Judg 10,1; 1 Chr 7,1-2). It does not concern all the passages since in two of them, Isa 1,8 i Lam 4,5, the noun şר should be counted into nouns of the textile terminology.

23 Brenner, Colour Terms, 143. 


\begin{tabular}{|c|c|c|}
\hline \multicolumn{3}{|c|}{ CRIMSON } \\
\hline HEBREW TERM & GREEK TERM & SIGLUM \\
\hline תוֹלַעַת שָשִני & 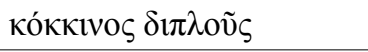 & Exod 25,4 \\
\hline ת תוֹלַעַת שִָׁני & 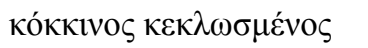 & Exod 26,1 \\
\hline 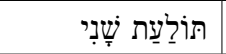 & 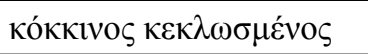 & Exod 26,31 \\
\hline ת תוֹלַעַת שִָׁני & 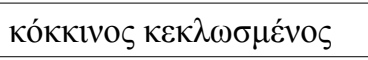 & Exod 26,36 \\
\hline ת תוֹלַעַת שִָׁני & 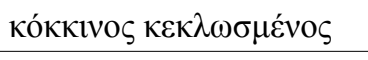 & Exod 27,16 \\
\hline 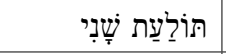 & Ко́ккıvоৎ & Exod 28,5 \\
\hline ת תוֹלַעַת שִָׁני & - & Exod 28,6 \\
\hline 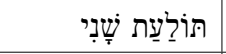 & 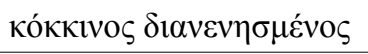 & Exod 28,8 \\
\hline ת תוֹלַעַת שִָׁני & 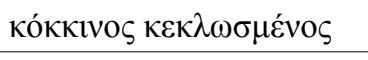 & Exod 28,15 \\
\hline ת תוֹלַעַת שִָׁני & 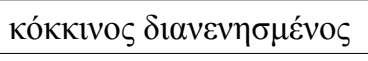 & Exod 28,33 \\
\hline ת תוֹלַעַת שִָׁני & 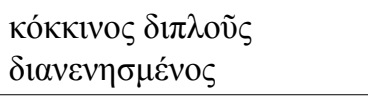 & Exod 35,6 \\
\hline ת תוֹלַעַת שָשִני & - & Exod 35,23 \\
\hline תוֹלַעַת שָשִני & 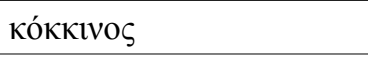 & Exod 35,25 \\
\hline תוֹלַעַת שָׁנִי & 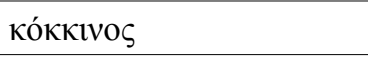 & Exod 35,35 \\
\hline תתוֹלַעַת שָׁנִ & $-1-$ & Exod 36,8 (HB); Exod 36,8/37,1 (LXX) \\
\hline ת תוֹלַעַת שִָׁני & 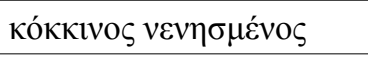 & Exod 36,35 (HB); Exod 37,3 (LXX) \\
\hline ת תוֹלַעַת שִָׁי & 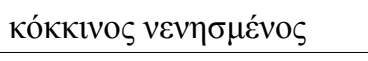 & Exod 36,37 (HB); Exod 37,5 (LXX) \\
\hline ת תוֹלַעַת שִָׁי & 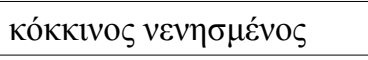 & Exod 38,18 (HB); Exod 37,16 (LXX) \\
\hline ת תוֹלַעַת שִָׁני & 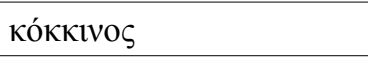 & Exod 38,23 (HB); Exod 37,21 (LXX) \\
\hline ת תוֹלַעַת שִָׁני & - / ко́ккıvоక & Exod 39,1 (HB); Exod 36,8/39,12 (LXX) \\
\hline | תוֹלַעַת שִָׁי & 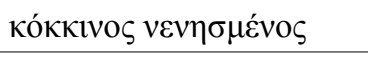 & Exod 39,2 (HB); Exod 36,9 (LXX) \\
\hline ת תוֹלַעַת שָׁנִי & 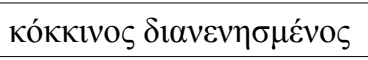 & Exod 39,3 (HB); Exod 36,10 (LXX) \\
\hline ת תוֹלַעַת שִָׁני & 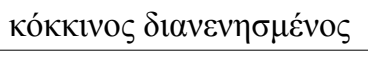 & Exod 39,5 (HB); Exod 36,12 (LXX) \\
\hline תתוֹלַעַת שִָׁני & 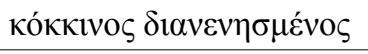 & Exod 39,8 (HB); Exod 36,15 (LXX) \\
\hline ת תוֹלַעַת שִָׁני & 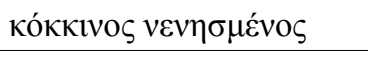 & Exod 39,24 (HB); Exod 36,31 (LXX) \\
\hline | תוֹלַעַת שִָׁי & 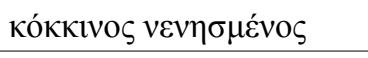 & Exod 39,29 (HB); Exod 36,36 (LXX) \\
\hline
\end{tabular}

It refers to this type of fabric as much as 26 times in the HB, and analogical term - adjectival ко́ккıvо - is used in the LXX 24 times. Dyed crimson yarns

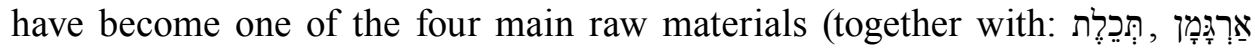
and שש $)$ used for the construction of the shrine and production of priestly vestment. Hebrew and Greek version of the texts are relatively consistent. In these

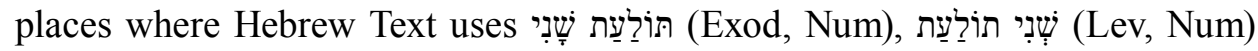




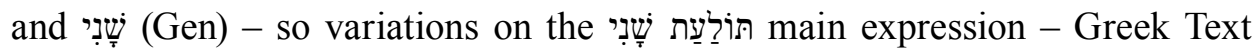
consequently uses already known adjective кóккıvoৎ.

Collection of Writings shows the diversity of terminology when it comes to the crimson. Next to the blue and Tyrian purple, crimson was to be used during the building of the Holy Temple.

\begin{tabular}{|c|c|c|}
\hline \multicolumn{3}{|c|}{ CRIMSOM } \\
\hline HEBREW TERM & Greek Term & SIGLUM \\
\hline כַּרְִִִיל & ко́ккıVо & $2 \mathrm{Chr} 2,6$ \\
\hline כַּרְִִיל & Ко́ккıvо & $2 \mathrm{Chr} 2,13$ \\
\hline כַּרְִִיל & Ко́ккıvоక & $2 \mathrm{Chr} 3,14$ \\
\hline
\end{tabular}

Chronicler in his works mentions crimson 3 times - due to the demand for skilfully weaving man $(2 \mathrm{Chr} 2,6)$, sending of craftsman $(2,13)$ and covering veil of the tabernacle $(3,15)$. However, while Exodus, when describing crimson, accustomed the recipient to the the Chronicler decided to use a different,

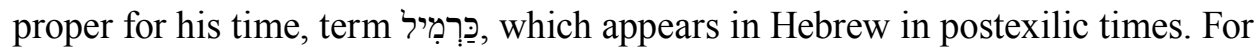
the LXX translators changing terminology does not make any difference - they

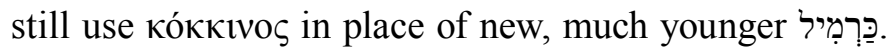

\section{Origins of שפוּ}

Hebrew wשis considered as quite early term within the biblical dictionary, mostly because it can be found in Pentateuch (such reasoning is conducted for example by Hurvitz ${ }^{24}$ ). From the modern Biblical Studies point of view however, such conclusion should be considered as outdated: it is becoming more and more clear today, that Pentateuch is not that ancient as thought - it origins most probably from the exilic period, with possible additions from Persian era. ${ }^{25}$ This statement is additionally legitimated by Knobloch by showing the postexilic elements in $\mathrm{P}$ as well as noticing that even if term $\underset{w}{\mathrm{i}}$ is ancient, it still could have been in use during much later periods. The same rationale applies to relatives are dated for as far as $9^{\text {th }}$ century $\mathrm{BC} .{ }^{26}$ And so, even if one doesn't have

24 Hurvitz, "The Usage of שש and ביוץ 120.

25 As representative one can treat the book of J.L. Ska, Introduzione alla lettura del Pentateuco: chiavi per l'interpretazione dei primi cinque libri della Bibbia (Collana Biblica; Bologna: EDB 2004). For further discussion see The Fall of Jerusalem and the Rise of the Torah (ed. P. Dubovský - D. Markl - J.-P. Sonnet) (Forschungen zum Alten Testament 107; Tübingen: Mohr Siebeck 2016).

26 Knobloch, "Linen and the Linguistic", 469nn. 
enough information to understand if this was due to stylization or maybe some early tradition, one can derive שׁ from Egyptian šś, which stands for "delicate linen" or "costly textile to make clothes with". ${ }^{27}$

When it comes to Brenner points out its Semitic origin without further doubts. Other authors, including Beekes and Beck, Hurvitz and Gaspa underline its Egyptian provenance, arguing that Egyptian $b \underline{d} 3$ - "pleated stuff" was imported to Levant with luxury material, which it defined. ${ }^{28}$ Brenner also interestingly mentions, that includes also the very idea of "whiteness". As a base for this conclusion, he uses words present in other Semitic languages, for example in Arabic 'abyad - "white" or Akkadian peșu - "white, transparent."2 ${ }^{29}$ Most probably also Greek $\beta v ́ \sigma \sigma o \varsigma$ has similar origin. ${ }^{30}$ Avi Hurvitz considers two moments to be symptomatic when it comes to origin of

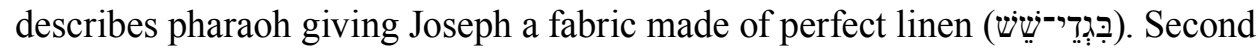

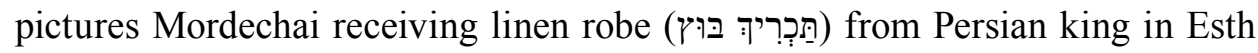
8,15 . Both scenes seem to indicate provenance of both terms as well as the time, where they become commonly used by Israelis. Younger, according to Hurvitz, term Y had to be adapted because of longer contact between Hebrew and its northern neighbours. And as we know, the best opportunity for such contact was during the Babylonian captivity.

It is not hard to prove, using Hebrew texts, that both most identical semantic range, but they differ when it comes to age. Hurvitz shows - evoking numerous examples - that older שw is present in the rabbinic literature, but only in citations. In all other texts, it is Term ששwwas in more common use by the writers from Qumran, however we can suspect, that they were trying to imitate biblical style - simply because in some places there are glosses in text, explaining the meaning of שש ${ }^{31}$ Still, we cannot underestimate the Hurvitz's critique by Knobloch, who argues that Source $\mathrm{P}$ - base of Book of Exodus - is, just like the work of Chronicler, postexilic text.

27 Also the "mummy bandages" and "alabaster vessels". Wörterbuch der Aegyptischen Sprache (ed. A. Erman - H. Grapow) (Berlin: Akademie Verlag 1971) III, 539-540.

28 See eg. S. Gaspa, "Garments, Parts of Garments, and Textile Techniques in the Assyrian Terminology: The Neo-Assyrian Textile Lexicon in the 1st-Millennium BC Linguistic Context", Textile Terminologies from the Orient to the Mediterranean and Europe, 1000 BC to $1000 \mathrm{AD}$ (ed. S. Gaspa - C. Michel - M.-L. Nosch) (Lincoln: Zea Books 2017) 60.

29 Taking into consideration the Semitic core byd, to which Brenner refers, it should be recognized that that similar implications can be found in the Hebrew 7 . The idea of "whiteness" referring to linen does not have to point to the quality of the fabric since a lower quality not debatable. Brenner, Colour Terms, 133, 148.

30 Beekes - Beck, Etymological Dictionary, 242; R. Rosół, Frühe semitische Lehnwörter im Griechischen (Frankfurt am Main: Peter Lang 2013) 30-31.

31 We are talking here about the adverb לָָ לָָ-, white". A. Hurvitz, A Concise Lexicon of Late Biblical Hebrew. Linguistic Innovations in the Writings of the Second Temple Period (SVT 160; Leiden - Boston: Brill 2014) 49-50. 


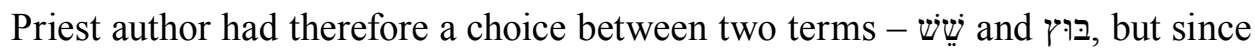
his aim was to keep the language as ancient as possible, he chose Egyptian שw. Taking above into account, it is hard to agree with Hurvitz's statement, that and ב should be considered as indicators of the age of the text. ${ }^{32}$ Therefore we cannot only limit ourselves to analysis of mentioned terms, but we need to

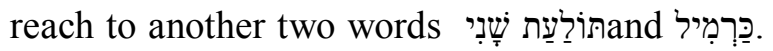

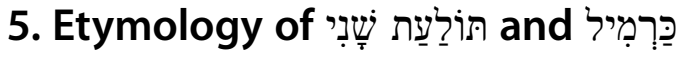

The list of terms describing crimson in Torah consists of only two basic nouns: שָנִי cases, considered as own name - the name Tola (Gen 46,13; Exod 26,23; Judg 10,1; $1 \mathrm{Chr} 7,12$ ), but in two cases it is identified as crimson (Isa 1, 18; Lam 4,5) per

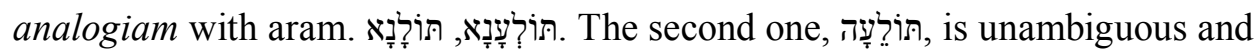
points to cochineal - larva, chrysalis or imago. Most linguists stress uncertain

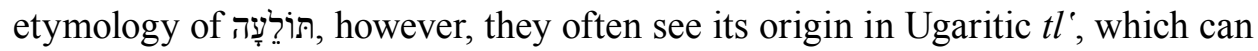
be interpreted as: a) worm, cochineal; b) roden, or a creature that bites; c) verbal "bite", but in the sense of corroding, rusting. In Syriac the similarly sounding noun $\operatorname{taul}^{\prime} \bar{a}$ also means a worm. The similar meaning have parallels from other Semitic languages: aram. $t w l^{\prime} h$, akkad. $t \bar{u} l t u(m)$, syr. taula'ta etc. $^{33}$ Because of the above premise, we can conclude that term sis was in fact quite ancient.

Noun which origin is also to the great extent uncertain, is on the other hand related (semantically) with Akkadian šinitu(m), often translated to "rinsing", "soaking", "dyeing", or just "dyed fabric". It is probably related to the arab. san $\bar{a}$ - sparkle or san $\bar{a}$ - "to shine". ${ }^{34}$ These identifications are unfortunately

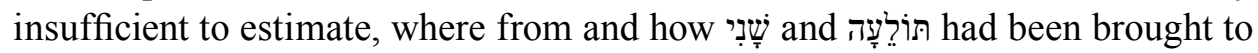
Hebrew. Their "very ancient" origin is the only factor we can identify.

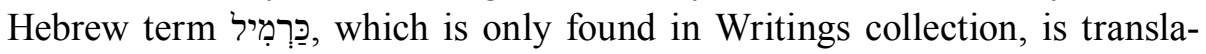
ted in LXX without further doubts: authors translate its meaning with Greek

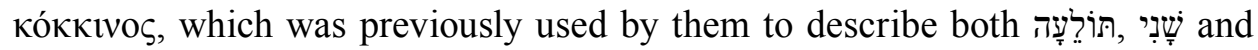

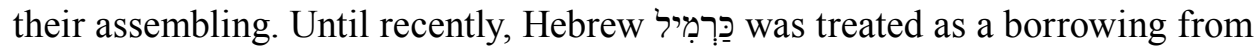
Persian kirm - "worm" or kirmīja - "produced by worms". ${ }^{35}$ This thesis about

32 Knobloch, "Linen and the Linguistic", 469-472.

33 L. Koehler - W. Baumgartner - J.J. Stamm (ed.), Wielki stownik hebrajsko-polski i aramejsko-polski Starego Testamentu (ed. pl. P. Dec) (PSB; Warszawa: Vocatio 2008) II, 638-639.

34 U. Cassuto, A Commentary on the Book of Exodus (trans. I. Abrahams) (Jerusalem: Magnes Press, Hebrew University 1997) 325.

35 L. Koehler - W. Baumgartner - J.J. Stamm (ed.), Wielki stownik hebrajsko-polski i aramejsko-polski Starego Testamentu (ed. pl. P. Dec) (PSB; Warszawa: Vocatio 2008) I, 470; E. Klein, A Comprehensive Etymological Dictionary of the Hebrew Language for Readers of English 
Persian origin of crimson in Semitic languages was criticized by Agnes Korn, who made an observation claiming that the concept of this word stemming from Persian comes from a mistake that spread in the 80 s by $A$ Concise Pahlavi Dictionary by Neila D. MacKenzey. The author claims that the Persian kirm ${ }^{36}$ appears in the text only once Zand $\bar{\imath}$ Wahman Yasn which beginnings are dated for the Sasanian times at the earliest. The term karmir which can be found in the same text, is most probably borrowed into Persian from other language, and

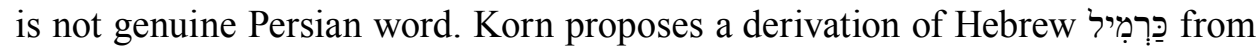
Indo-European kurmi, which stands for "worm" or "grub". This word supposedly mad its way to Middle East because of wide-range manufacturing of crimson in

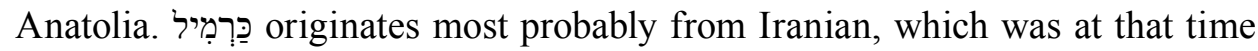
spoken in Armenia. ${ }^{37}$

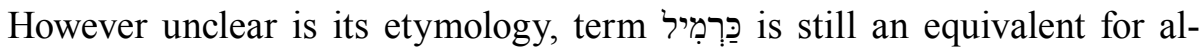

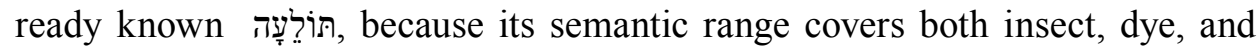
even crimson clothing. In that case, even if Korn is right in her critique, most

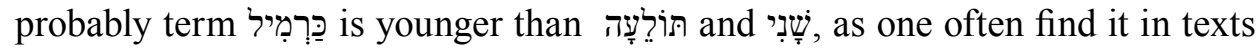
younger than Bible. ${ }^{38}$

\section{Greek version of the Hebrew terms - translation or adaptation?}

The lists presented above also prompt the questions about the Greek equivalents of the Hebrew terms. Already a brief observation leads to conclusions. Firstly, the translators of the Greek texts show an unusual consequence using the terms $\beta v ́ \sigma \sigma o \varsigma$ and $\beta v ́ \sigma \sigma ı v o \zeta$, when they discuss byssus. Secondly, the translators are aware of the meaning of the Hebrew terms despite the significant changes they undergo. They decide then for a language unification that needs to have its source. Indicating it requires the answer to the question how much the presented terms reflect the situation in the textile market and if showing the terminological

(Jerusalem: Carta 1987) 287. These, on the other hand, were to come from the Old Indic kirmih -, ,worm”. According to Hartey, the Biblical term has its source in Persian, which, on the other hand, stemmed from Sanskrit. J.E. Hartley, The Semantics of Ancient Hebrew Colour Lexemes (ANESSup 33; Louvain: Peeters 2010) 207.

36 Hartley notes the presence of kirm pilla - "silkworm" in Persian as well. Hartley, The Semantics, 207.

37 A. Korn, “Arménien karmir, sogdien krm'yr et hébreu karmīl «rouge»”, Bulletin of SOAS 1/79 (2016) 1617.

38 Poprzestawiany przypis. Powinno być: The terms related to language $(\mathrm{krm} \bar{\imath})$ and in Arabic (qirmizī). Klein, A Comprehensive Etymological Dictionary, 287; Cassuto, A Commentary, 325. 
differences happening in the Hebrew language had any justification - especially in the Alexandrian environment.

The origin of the noun $\beta$ v́$\sigma \sigma o \varsigma$ and its derivatives does not raise any doubts. As it was noted before its etymology is most probably connected with the Hebrew

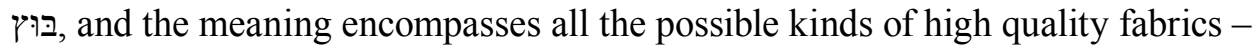
linen, cotton and silk. There is no doubt though that the Bible does not mention cotton or silk, ${ }^{39}$ and the Hebrew nouns mean excellent linen fabrics. Were the translators then able to reflect the change noticed in the Hebrew terminology in

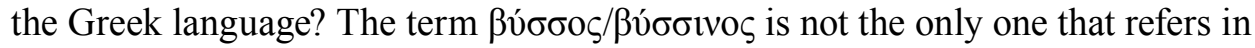
LXX to linen. One records in it also 7 other equivalents: $\lambda$ ívov, $\lambda$ ıvoṽ $\varsigma$ - „flax,

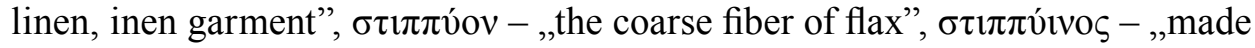

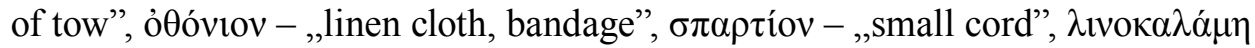

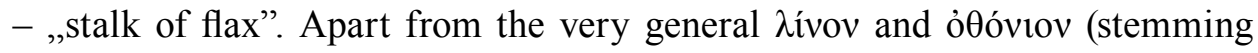
from the Semitic languages), the rest of the terms should be excluded from the list of delicate linen equivalents. As far as the noun $\lambda$ ívov/ $\lambda$ ivoṽ $\varsigma$ is concerned, it appears in a couple of books which show its wide semantic range, it means namely: a linen fabric of possibly average quality (Exod 28, 42; Lev 6,3; Ezek 44,18; Prov 31,13), ${ }^{40}$ linen threads or yarns (Lev 13,48.52), wicks (Isa 42,3; 43,17), higher quality fabrics intended for priests sacred garments (Lev 16,23.32; Ezek 44,17), women's clothing (Jdt. 16,8) and plants (Exod 9,31). It would not be a proper

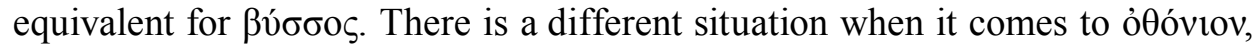
a fabric that was in general use in Egypt. The both terms that accompany this

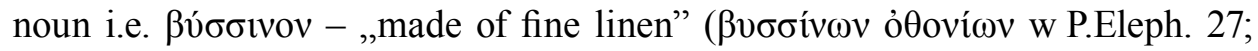

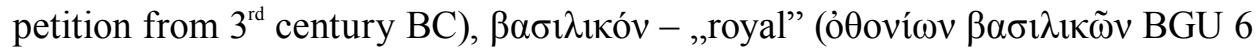
1376, a tax receipt from $2^{\text {nd }}$ century BC, see O.Ashm. Shelt. 3; O.Camb. 6 itd.), $\lambda \varepsilon \pi \tau$ óv - „thin, fine” (ỏĐovíov $\lambda \varepsilon \pi \tau$ oṽ w P.Köln 8 346, a bill from III century BC.) in the Papyrus texts and on ostraca unambiguously indicate that they mean a high quality linen canvas. ${ }^{41}$

On the basis of documentary sources one can draw a conclusion, but it is a rather unreliable one, that whereas ó $\theta$ óviov was commonly in a secular use, in a sacral sphere $\beta u ́ \sigma \sigma o \varsigma$ was used (it was e.g. used in producing garments for gods (see P. Strasb. 2 91; P. Lund. 4 11). ${ }^{42}$ On the other hand though, protein

39 Cf. O. Shamir - N. Sukenik, "Qumran Textiles and the Garments of Qumran's Inhabitants", Dead Sea Discoveries 18 (2011) 213-214.

40 The trousers of priests had probably also the function of underwear that is why their quality did not have to be high since they were worn under other garments.

41 Based on www.papyri.info (access: 10.09.2017); It is also confirmed by Philo, Spec. Leg. 1,84; Tacitus 18,12; Josephus Ant. 5,290; 12,117. Zob. C. Spiq, Theological Lexicon of the New Testament (trans. J.D. Ernest) (Peabody: Hendrickson Publishers 1994) II, 564-565.

42 It would correspond perfectly with the Bible texts, in which $\beta v 6 \sigma 0 \varsigma$ is present in the description of the priests' garments, in the building of a tabernacle or when it constitutes the king's 
linen was produced mainly in state workshops operating by temples, ${ }^{43}$ which produced fabrics for both, the secular and cult use. What also raises doubts though is a fact that ó $\theta$ óviov does not constitute a Greek equivalent of wש, or of but for and linen stems (in plural form). ${ }^{44}$ The choice of the term may not be explained only by help of a Hebrew text since in other books of LXX

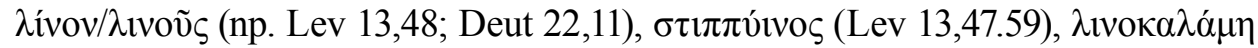
(Josh 2,9) etc., but by a translators decision, who for reason unknown believed

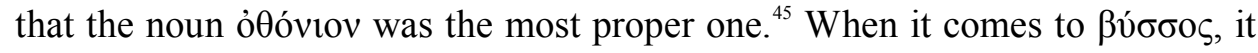
is difficult to say that using it in translation of שי

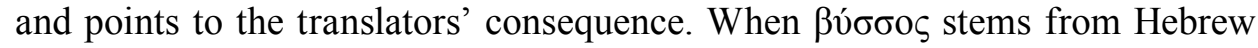
and Egyptian it is difficult to find a semantically close Greek term by which both the Hebrew terms could be translated to. No wonder then that the translators did not decide to convey the nuance included in the original text. It is difficult then to say about any strategy underlying the translation of textile terms into Greek. However, what needs to be noticed and stressed in Knobloch's favor, both terms - שיש, and - has been well known to LXX translators and, in some way, they treated them as synonymous.

When ко́ккıvoৎ is discussed though, Matteo Martelli believes that this term that means "crimson" constitutes the name of a color that does not suggest a source of the dye used to dye the fabrics. ${ }^{46}$ Martelli deduces this in spite of a clear morphological kinship with the noun кóкко, , which means „kermes”, even though its original meaning is rather ,pit”, first of all the (fruit of) pomegranate and, according to Theophrastus, a berry or a gall from the crimson oak or the

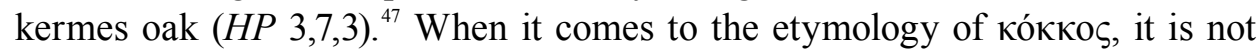
known, but it is suggested that its original term could have been the Mediter-

garments whereas ó $\theta$ óviov is authenticated only in the secular context. The second term appears too seldom to create a rule out of the above statement.

43 W.E. Glenny, Hosea. A Commentary Based on Hosea in Codex Vaticanus (SCS; Leiden - Boston: Brill 2013) 75.

44 Koehler, Wielki stownik, II, 65.

45 In this way, the translator changed a bit the meaning of the texts of The Book of Hosea, since whereas the Hebrew text emphasizes that Gomer would receive from her lovers the items necessary to survive, the pastoral and agricultural products, the Greek text suggests that at least the fabrics belonged to luxury goods. Cf. F.I. Andersen - D.N. Freedman, Hosea. A New Translation with Introduction and Commentary (AB 24; New York: Doubleday 1980) 232; Glenny, Hosea, 76

46 M. Martelli, "Alchemical Textiles. Colourful Garments, Recipes, and Dyeing Techniques in Greco-Roman Egypt", Greek and Romans Textiles and Dress: An Interdisciplinary Anthology (ed. M. Harlow - M.L. Nosch) (ATS 19; Oxford: Oxbow Books 2014) 125.

47 A Greek-English Lexicon (ed. H.G. Liddell - R. Scott - H.S. Jones) (Oxford: The Clarendon Press 1996) 970-971. 


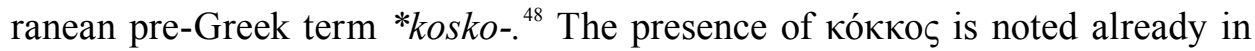
the Homeric Hymns, but the adverb form кóккıюৎ appears for the first time in $5^{\text {th }}$ century $\mathrm{BC}$, and its frequency in the Greek writings rises significantly only from $3^{\text {rd }}$ century BC on, ${ }^{49}$ so in the period of LXX forming.

In the Egyptian documents dated for the Hellenic period and the early Roman one even though кóккıvoৎ does not appear often it always does in the contexts connected with clothing and jewelry, e.g. in BGU 71666 from I century po Chr.

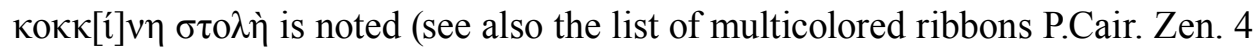
59696 from $3^{\text {rd }}$ century BC or a private letter from II century BC BGU 6 1300)..$^{50}$ What is then the term the translators could replace (could have replaced) the

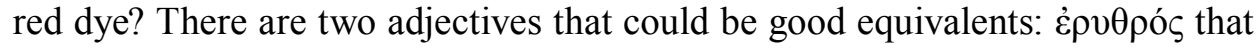
appears in the Bible quite commonly (32x) and poivıкoũ $\varsigma$ used in Isa 1,18 to translate the Hebrew שָׁ. While the former appears in the Bible almost solely accompanied by the noun $\theta \alpha \dot{\lambda} \alpha \sigma \sigma \alpha$, composing with it the name Red See (only once pointing to the color of the fabric in Isa 63,2 ), the latter is present only once. ${ }^{51}$ Even though the adverb poivikoũ $\varsigma$ is present in the Greek literature it should be considered as an equivalent that was not very promising since it was not popular in the everyday life. It could have seemed to the translators as rather imprecise if it was associated not only with crimson but also with purple (cf. name Phoenicia). ${ }^{52}$ The choice of ко́ккоц/ко́ккıvоৎ and the unification of translation did not come from the adopted strategy but the necessity. It can be then stated that even if this conclusion is not fully eligible, the decisions of the LXX translator were conditioned not only by the situation on the Egyptian textile market where

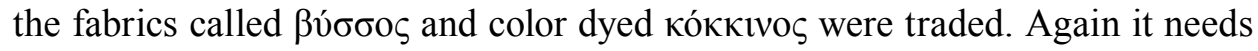

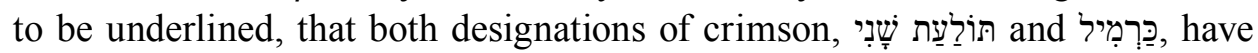
been known to translators, which will not be meaningless for our conclusions. When it comes to an equally popular fabric óob́viov, it should be believed that

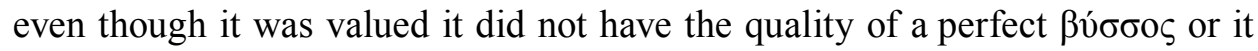
was too strongly associated with mummy bandages that were made of it.

48 Beekes - Beck, Etymological Dictionary, 733; Cf. P. Chantraine, Dictionnaire etymologique de la langue grecque: histoire des mots (Paris: Klincksieck 1970) 553.

49 Data based on TLG http://stephanus.tlg.uci.edu/ (access: 10.09.2017).

50 www.papyri.info (access: 07.09.2017).

51 According to the data from the papyri.info database (access: 07.09.2017), the adverb poivıкоv $\varsigma$ was not recorded in the Greek Papyrus documents and ostraca, and the related terms are to be understood as dactyls.

52 A Greek-English Lexicon, 1947. 


\section{Conclusions}

When we look at above analysis, the most visible and, let's say, obvious thing is consequence in translation practice of Greek authors. Despite sometimes serious differences within Hebrew terminology, Greeks unified translations on one hand, and used transcriptions for the words they didn't understand - on the other: as it happened with $\alpha \beta \alpha \kappa$ replacing Hebrew 1 in $1 \mathrm{Chr} 4,21$. Such unification was dependent on the deep knowledge of Hebrew terminology which means,

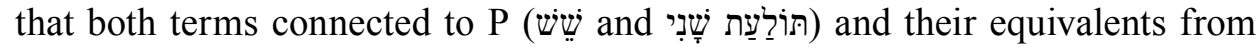

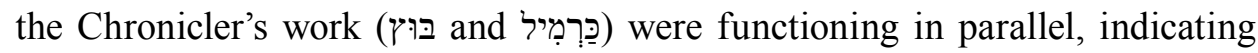
only a difference in origin of particular fabrics. And since they were still in use in 3rd century BC, when LXX was taking its shape, they were well known to both compilers of Exodus and to Chronicler.

Following above reasoning, more difficult question appears, where we are trying to explain the differences in Hebrew version of the text itself. Why "byssus" in Pentateuch is hidden under name שw, then Prophets refer to it using both שֶ and and finally in Writings only second terms is used? The origin of these two terms: שִ - from Egypt and from Persia, seems to be a key to this riddle for Hurvitz. He without a doubt claims, that Babylonian Exile was the best moment for an exchange between these two languages - should the change in terminology be then a pure result of the time when they were written down? Book of Esther seems to hold an answer to that question: its author sticks solely to the noun . Aramaic Targums. Following this reasoning, Exodus can be connected with the period in history of Israel, when it held close relations with Egypt - and when it took its Promised Land. Similar process would affect also terms describing

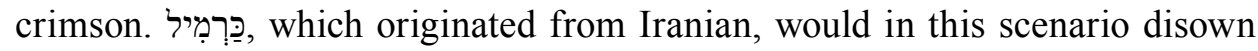

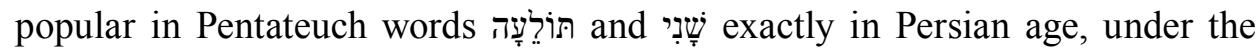
influence of a local language. Such a strong representation of a new vocabulary allows us to date Books of Chronicles on turn between $6^{\text {th }}$ and $5^{\text {th }}$ century BC.

Above conclusions would not be complete without considering Knobloch's arguments. As he points out, selection of terminology was not as much the result of a chronology as it was determined by linguistic tradition - the one carefully cultivated by priest writers and underestimated by the prophets and Chronicler. Let us notice, however, that Konbloch's polemics does not negates Hurvitz's conclusions, it rather corrects and supplements them. Priest's source, even if it really comes from postexilic times, carries much older tradition, the one that reaches pre-exilic period. Moreover, it is hard to imagine, that priest writers describing

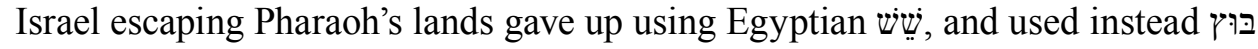
associated with Mesopotamia and Anatolia. We must agree then with Knobloch 


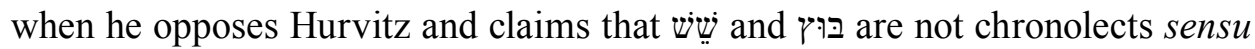
stricto, but rather topolects. Knobloch, however being right in above reasoning, missed another - and, I have a reason to believe, very important - pair of terms

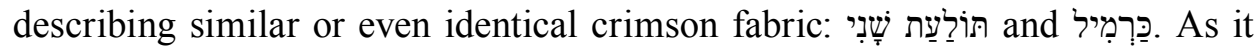
has been mentioned previously, both terms can be used as indicators of the time and place of their own origin. This is true especially for the one used by the

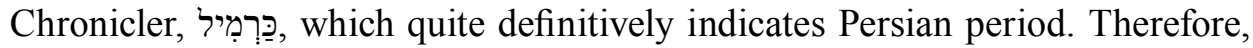

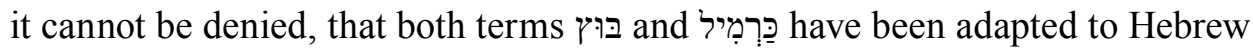
language not only due to linguistic processes but also, or rather mainly, because of the changes in textile market during and after Babylonian exile - which makes these terms both chronolects and topolects. Most probably in postexilic period, when contacts and trade with Egypt had been weaker, the noble and expensive שׁ simply disappeared from Judean markets. And writers from Persian period reached out to terms describing well known and more common fabrics. In this context $\mathrm{P}$ dated on exilic and postexilic periods ${ }^{53}$ is, according to Knobloch and Robert Polzin, ${ }^{54}$ an excellent example of conservative approach to tradition by Hebrew priesthood as well as a proof of stylization and/or archaization of language, used to strengthen its authority. Similar tactics in relation to sacred texts is commonly used also nowadays. Taking into account Chronicler's works and tradition preserved by priest writers (rather than looking at the final redaction of the texts) we can conclude, that both Hurvitz and Konbloch are correct in their statements, even though they often look at the same problems from different perspectives.

\section{Bibliography}

Allen, L.C., The Greek Chronicles. The Relation of the Septuagint of I and II Chronicles to the Masoretic Text (Leiden: Brill 1974).

Amar, Z. - Gottlieb, H. - Varshavsky, L., "The Scarlet Dye of the Holy Land", Bioscience 12/55 (2005) 1080-1083.

Beekes, R. - Beck, L. van, Etymological Dictionary of Greek (LIEEDS 10, Leiden -Boston: Brill 2009) I-II.

Brenner, A., Colour Terms in the Old Testament (JSOTSS 21, Sheffield: JSOT Press 1983).

Bush, F.W., Ruth/Esther (WBC 9, Dallas: Word Books Publisher 1971).

Cassuto, U., A Commentary on the Book of Exodus (trans. I. Abrahams) (Jerusalem: Magnes Press, Hebrew University 1997).

53 Knobloch, "Linen and the Linguistic", 470-473.

54 See R. Polzin, Late Biblical Hebrew. Toward an Historical Typology of Biblical Hebrew Prose (KSM 12; Missoula: Scholars Press 1976). 
Chantraine, P., Dictionnaire etymologique de la langue grecque: histoire des mots (Paris: Klincksieck 1970).

The Fall of Jerusalem and the Rise of the Torah (ed. P. Dubovský - D. Mark1 - J.-P. Sonnet) (Forschungen zum Alten Testament 107; Tübingen: Mohr Siebeck 2016).

Forbes, R.J., Studies in Ancient Technology (Leiden: Brill 1956) IV.

Gardiner, A. H., "Two hieroglyphic signs and the Egyptian words for «Alabaster» and «Linen»", Bulletin de l'institut francais d'archeologie orientale 30 (1930) 161-183.

Gaspa, S., "Garments, Parts of Garments, and Textile Techniques in the Assyrian Terminology: The Neo-Assyrian Textile Lexicon in the 1st-Millennium BC Linguistic Context", Textile Terminologies from the Orient to the Mediterranean and Europe, 1000 BC to 1000 AD (ed. S. Gaspa - C. Michel - M.-L. Nosch) (Lincoln: Zea Books 2017) 47-90.

Gesenius, W., A Hebrew and English Lexicon of the Old Testament with Appendix Containing the Biblical Aramaic (trans. E. Robinson) (Boston - New York - Chicago: The Riverside Press 1906).

Glenny, W.E., Hosea. A Commentary Based on Hosea in Codex Vaticanus (SCS; Leiden -Boston: Brill 2013).

A Greek-English Lexicon (ed. H.G. Liddell - R. Scott - H.S. Jones) (Oxford: The Clarendon Press 1996).

Harlow, M. - Nosch, M.-L., "Weaving the Threads: Methodologies in Textile and Dress Research for the Greek and Roman World - the State of the Art and the Case for Cross-Disciplinary", Greek and Romans Textiles and Dress: An Interdisciplinary Anthology (ed. M. Harlow M.L. Nosch) (ATS 19; Oxford: Oxbow Books 2014) 1-33.

Hartley, J.E., The Semantics of Ancient Hebrew Colour Lexemes (ANESSup 33; Louvain: Peeters 2010).

Hurvitz, A., A Concise Lexicon of Late Biblical Hebrew. Linguistic Innovations in the Writings of the Second Temple Period (SVT 160; Leiden - Boston: Brill 2014).

Hurvitz, A., "The Usage of ש Harvard Theological Review 1/60 (1967) 117-121.

Klein, E., A Comprehensive Etymological Dictionary of the Hebrew Language for Readers of English (Jerusalem: Carta 1987).

Knobloch, F.W., "Linen and the Linguistic Dating of P", Mishneh Todah. Studies in Deuteronomy and its Cultural Environment in Honor of Jeffrey H. Tigay, (ed. N.S. Fox - D.A. Glatt-Gilad - M.J. Williams) (Winona Lake: Eisenbrauns 2009) 459-474.

Knoppers, G.N., I Chronicles 1-9: A New Translation with Introduction and Commentary (AB 12; New York - London - Toronto: Doubleday 2004).

Koehler, L. - Baumgartner, W. - Stamm J.J. (ed.), Wielki stownik hebrajsko-polski i aramejsko-polski Starego Testamentu (ed. pl. P. Dec) (PSB; Warszawa: Vocatio 2008) I-II.

Koren, Z.C., "The Colors and Dyes on Ancient Textiles in Israel", Colors from Nature: Natural Colors in Ancient Times (Tel Aviv: Eretz Israel Museum 1993) 15-31.

Korn, A., "Arménien karmir, sogdien krm'yr et hébreu karmīl «rouge»”, Bulletin of SOAS 1/79 (2016) 1-22.

Lervad, S. - Mathiassen T.E., "textilnet.dk - A Toolkit for Terminology Research and Presentation", Textile Terminologies from the Orient to the Mediterranean and Europe, 1000 BC to $1000 \mathrm{AD}$ (ed. S. Gaspa - C. Michel - M.-L. Nosch) (Lincoln: Zea Books 2017) 528-537.

Maeder, F., "Irritating Byssus - Etymological Problems, Material Facts, and the Impact of Mass Media", Textile Terminologies from the Orient to the Mediterranean and Europe, 1000 BC to $1000 A D$ (ed. S. Gaspa - C. Michel - M.-L. Nosch) (Lincoln: Zea Books 2017) 500-519. 
Martelli, M., "Alchemical Textiles. Colourful Garments, Recipes, and Dyeing Techniques in Greco-Roman Egypt", Greek and Romans Textiles and Dress: An Interdisciplinary Anthology (ed. M. Harlow - M.L. Nosch) (ATS 19; Oxford: Oxbow Books 2014) 111-130.

Oppenheim, A.L., "Essay on Overland Trade in the First Millennium B.C.”, Journal of Cuneiform Studies 21 (1967) 236-254.

Polzin, R., Late Biblical Hebrew. Toward an Historical Typology of Biblical Hebrew Prose (KSM 12; Missoula: Scholars Press 1976).

Rosół, R., Frühe semitische Lehnwörter im Griechischen (Frankfurt am Main: Peter Lang 2013).

Schiffman, L.H., The Courtyards of the House of the Lord. Studies on the Temple Scroll (STDJ 75; Leiden - Boston: Brill 2008).

Shamir, O., "Textile Production in Eretz-Israel", Michmanim 16 (2002) 18-32.

Shamir, O. - Sukenik, N., "Qumran Textiles and the Garments of Qumran's Inhabitants", Dead Sea Discoveries 18 (2011) 206-225.

Ska, J.L, Introduzione alla lettura del Pentateuco: chiavi per l'interpretazione dei primi cinque libri della Bibbia (Collana Biblica; Bologna: EDB 2004).

Sukenik, N., „Dyes in Eretz Israel in the Roman Period, in Light of the Textile Findings from the Judean Desert Caves", Cathedra 154 (2014) 7-28.

Szczepanowicz, B., Moda w Biblii (Kraków: Wydawnictwo Księży Sercanów DEHON 2011).

Tronina, A., Pierwsza Księga Kronik (NKBST 10/1; Częstochowa: Edycja Świętego Pawła 2015).

Wörterbuch der Aegyptischen Sprache (ed. A. Erman - H. Grapow) (Berlin: Akademie Verlag 1971) III. 